\section{Willingness to Pay for a Specialty Blend Compost Product Developed from Brown Seaweed Harvested from Coastal Regions in Texas}

\author{
Tina M. Waliczek ${ }^{1}$, Nicole C. Wagner ${ }^{1}$, and Selin Guney ${ }^{2}$
}

ADDITIONAL INDEX WORDS. aquatic plant management, beach management, brown algae, compost quality, consumer preferences, exotic, invasive species, Sargassum fluitans, Sargassum natans

SUMMARY. Composting is the biological decomposition of organic materials, such as plant tissue, food scraps, paper, animal fodder, and wood chips. The end-product, compost, is a beneficial soil amendment because it can contain a diversity of beneficial microorganisms, has high nutrient and water-holding capacities, can increase total soil porosity, and contains essential plant nutrients that improve soil productivity. Coastal regions of the Gulf of Mexico, as well as the Atlantic and European shorelines, have witnessed a proliferation of brown seaweed (Sargassum sp.). When piled on beaches, tourism appeal is reduced, threatening the local economy. When amassed offshore, thick brown seaweed mats can hinder fishing. Excessive decomposition rates can lead to eutrophication, which threatens coastal areas economically and environmentally. Despite these problems, seaweed may be considered a valuable compost ingredient. Therefore, the purpose of this study was to conduct a market test to determine the potential value of a seaweed-incorporated compost to consumers in Texas and to identify attributes of likely consumers. A marketing survey was developed and distributed to gardeners in the central and south Texas regions. Contingent valuation questions measured participants' willingness to pay for the seaweed compost products. Participants were able to see, smell, and touch a sample of the compost while completing the survey. Despite $92 \%$ of respondents ranking themselves as inexperienced in compost behavior, results indicated a potential for a specialty, competitively priced seaweed-incorporated compost to be introduced to the market. Respondents were most willing to pay $\$ 4.00 / \mathrm{ft}^{3}$ to $\$ 5.00 / \mathrm{ft}^{3}$ for seaweed-incorporated compost. Additionally, participants who responded positively to buying local, buying compost in the past, having positive environmental attitudes, and buying American were more likely to pay more for the seaweed-incorporated compost. There was not an obvious pattern between willingness to pay for seaweed-incorporated compost and demographic responses.

$\mathrm{I}$ ncreasingly, composting is used as a waste management method for a variety of organic materials (Walker et al., 2006). Composting is the biological decomposition of organic and "waste" materials, such as

Received for publication 23 Sept. 2019. Accepted for publication 10 Feb. 2020.

Published online 14 April 2020

${ }^{1}$ Department of Agricultural Sciences, Texas State University, 601 University Drive, San Marcos, TX 78666

${ }^{2}$ School of Accounting, Finance, and Economics, University of Waikato, Private Bag 3105, Hamilton 3240, New Zealand

T.M.W. is a Professor of Horticulture.

N.C.W. is an Assistant Professor.

S.G. is a Senior Lecturer.

T.M.W. is the corresponding author. E-mail: tc10@ txstate.edu.

This is an open access article distributed under the CC BY-NC-ND license (https://creativecommons.org/ licenses/by-nc-nd/4.0/).

https://doi.org/10.21273/HORTTECH04511-19 plant tissues, food scraps, paper, animal fodder, and wood chips, into a soil-like product called "compost" (Rynk, 1992). The humus-like end product becomes a valuable soil amendment because it increases levels of organic matter (Laudicina et al., 2011), contains essential plant macro and micronutrients (Emerson, 2003; Faucette et al., 2003), stimulates microbial activity (Iovieno et al., 2009), and improves soil water-holding capacity and soil structure, which in turn reduces runoff, drought damage to plants, and the need for fertilizers
(Dougherty, 1999; Foley and Cooperband, 2002; Rynk, 1992).

Coastal regions of Texas have a proliferation of brown seaweed (Sargassum sp.) drifting onshore especially in the spring and early summer months, which overlaps with peak tourist seasons (Sembera et al., 2018). An excess of the seaweed is harvested in all major beach areas including Galveston, Port Aransas, Corpus Christi, South Padre Island, and Mustang Island. While brown seaweed can provide food and habitat for a diversity of marine life, excessive growth of seaweed threatens coastal areas economically and environmentally. Tourists often view the seaweed mats as poor beach maintenance (Gaskill, 2015). Because these areas rely on income generated from tourists, maintaining or increasing the tourism industry is essential (Gaskill, 2015). Additionally, excessive brown seaweed is considered a nuisance because it clogs recreational boating and fishing areas, as well as traps debris. Environmentally, excessive decomposition of this organic matter can lead to eutrophication (Eyras et al., 1998) and can entrap marine life (Langin, 2018). In 2011, brown seaweed was added to the Global Invasive Species Database (Invasive Species Specialist Group, 2011).

While excessive, nonnative brown seaweed biomass can have serious negative implications as described above, seaweed can be used a beneficial agricultural input. For centuries, species of seaweed have been applied directly to land to enhance plant growth and productivity, particularly in coastal areas (McHugh, 2003). Seaweeds and seaweed liquid fertilizers are commercialized and substituted for synthetic fertilizers. As reported by Begum et al. (2018), seaweed extracts are marketed as liquid fertilizer and bio-stimulants because they contain multiple growth regulators, such as cytokinins (Durande et al., 2003), auxins (Sahoo, 2000), and gibberellins (Strik and Staden, 1997). Applied to crops, seaweed extracts have

\begin{tabular}{llll}
\hline $\begin{array}{l}\text { Units } \\
\begin{array}{l}\text { To convert U.S. to SI, } \\
\text { multiply by }\end{array}\end{array}$ & U.S. unit & SI unit & $\begin{array}{l}\text { To convert SI to U.S., } \\
\text { multiply by }\end{array}$ \\
\hline 0.0283 & $\mathrm{ft}^{3}$ & $\mathrm{~m}^{3}$ & 35.3147 \\
3.7854 & $\mathrm{gal}$ & $\mathrm{L}$ & 0.2642 \\
0.4536 & $\mathrm{lb}$ & $\mathrm{kg}$ & 2.2046 \\
1.6093 & $\mathrm{mile}(\mathrm{s})$ & $\mathrm{km}$ & 0.6214
\end{tabular}


additional benefits including the promotion of beneficial soil microorganisms (Khan et al., 2009), increased plant nutrient uptake from soil (Turan and Köse, 2004), enhanced antioxidant properties (Verkleij, 1992), increased crop tolerance to environmental stress (Zhang et al., 2003), and increased crop resistance to some pests, such as red spider mites (Tetranychus urticae) and aphids (Aphidoidea) (McHugh, 2003). Furthermore, seaweed and liquid seaweed manures appear to induce fruit setting and increase germination rates (McHugh, 2003; Sivasankari et al., 2006). The increased crop germination rate at low concentrations of added seaweed extract could be due to growth promoting gibberellins, as well as additional micronutrients and amino acids that positively influence crop germination (Begum et al., 2018). Given these beneficial attributes, seaweed is applied as a green manure, foliar spray, soil conditioner, and/or soil drench (Thirumaran et al., 2009).

In areas where excess brown seaweed can be an economic and environmental detriment, initiatives have been implemented to compost brown seaweed due to its value as a soil amendment and fertilizer (Eyras et al., 1998; Illera-Vives et al., 2015; LópezMosquera et al., 2011; Sembera et al., 2018). By analyzing $\mathrm{pH}$, soluble salt content, macro and micronutrient content, carbon:nitrogen ratio, percent solids, and percent moisture content of composted brown seaweed, Sembera et al. (2018) found that compost created from brown seaweed resulted in a quality product for the horticultural industry. Although the quality of some brown seaweed compost can be limited due to high amount of sand and low nitrogen content, compost developed from seaweed has shown to increase soil water-holding capacity, plant growth, and plant macro and micronutrient uptake (Eyras et al., 1998; Illera-Vives et al., 2015; Michalak et al., 2017). Additionally, tomato (Solanum lycopersicum) grown with seaweed compost matured more quickly and showed higher resistance to disease (Eyras et al., 2008). While more research is needed to fully understand the mechanisms for these increases in yield and disease resistance, it is recognized that seaweed, which would otherwise be a waste product, can be of significant value as a composted material when used as a soil amendment (Cole et al., 2016).

The global compost market is expected to reach $\$ 9.2$ billion by 2024 (PR Newswire, 2019). Within the compost industry, there has been some differentiation in products available and the prices at which they were offered based on the ingredients from which the compost was made (Walker et al., 2006). For instance, composts prepared from municipal sewage waste are generally sold at a lower price when compared with compost created with animal manures (Garden-Ville, unpublished data). Landscape blends created with topsoil, mulch, and/or sand are promoted and offered for alternative applications (Garden-Ville, unpublished data). Knowledgeable and informed consumers will often recognize that not all composts have the same attributes and that various ingredients may have differing effects, limitations, and/or benefits (Alexander, 2019). With the understanding that various compost ingredients can demand different price points and that this may be a novel product for some consumers, it is important to establish whether the potential consumers are actually interested in the product as well as identifying the potential consumers (Glover et al., 2014; van Kleef et al., 2005).

Studies have shown that consumers are influenced by their personal values. For example, one study found most consumers would buy fewer imported products if they knew the distance products had traveled (Gairdner, 2006). Hence, more interest was garnered by consumers of other types of agricultural and horticultural products regarding local sourcing (Getter and Behe, 2013; Yue et al., 2011; Zaffou and Campbell, 2016). Additionally, some consumers were affected by ethnocentricity-where they are more likely to buy products made in the United States or in their home state. For example, in Texas, the "Go Texan" campaign was developed by the Texas Department of Agriculture and is used to promote Texas products and producers (Willcox, 2015).

Thus, the purpose of this study was to conduct a market test to determine the potential value of seaweed-incorporated compost to consumers in Texas and to identify attributes of likely consumers.

\section{Materials and methods}

Brown SEAWEed COMPost. The compost used in this study was created with $48 \%$ food waste, $48 \%$ regional wood chips, and $4 \%$ dried brown seaweed by volume collected from the U.S. Gulf Coast of Texas. The compost was tested by the Agricultural Analytical Services Laboratory's U.S. Composting Council's Seal of Testing Approval Program at Pennsylvania State University (University Park) and found to be a quality product for horticultural and agricultural applications (Sembera et al., 2018).

SAMPLE RECRUITMENT AND SURVEY ADMINISTRATION. Individual consumers were surveyed during the spring and summer at central Texas locations where gardeners were known to gather including local garden centers, farmer's markets, the university, community centers, and churches. Targeting farmers' market patrons allowed researchers to include individuals in the study who were predisposed to participating in niche markets. This type of relationship marketing has been used to predict consumer behavior and potential markets in past studies (Shani and Chalasani, 1992; Short et al., 2017).

Consumers were presented with a 1/2-gal bucket of the specialty compost to view, feel, and smell. Participants took $15 \mathrm{~min}$ on average to fill out the survey, and an incentive of a packet of seeds was used to encourage participation in the study. To have consistency in presenting the survey to participants, only one researcher administered the survey.

SURVEY InSTRUMENT. The survey included sections measuring environmental attitudes and behaviors, and behaviors related to purchasing habits such as ethnocentricity, locality, behavioral intent, and willingness to pay (WTP) for the product (Table 1). Demographic information was also collected for each participant, including age, gender, and educational and income level. The survey instrument and sections were adapted from previous studies known to be reliable and valid (Cornelissen et al., 2008; Glover et al., 2014; Short et al., 2017). For each section and variable of interest 
Table 1. Descriptive statistics indicating the frequency and percentages of responses to individual statements in the study of the market potential of seaweed-incorporated compost.

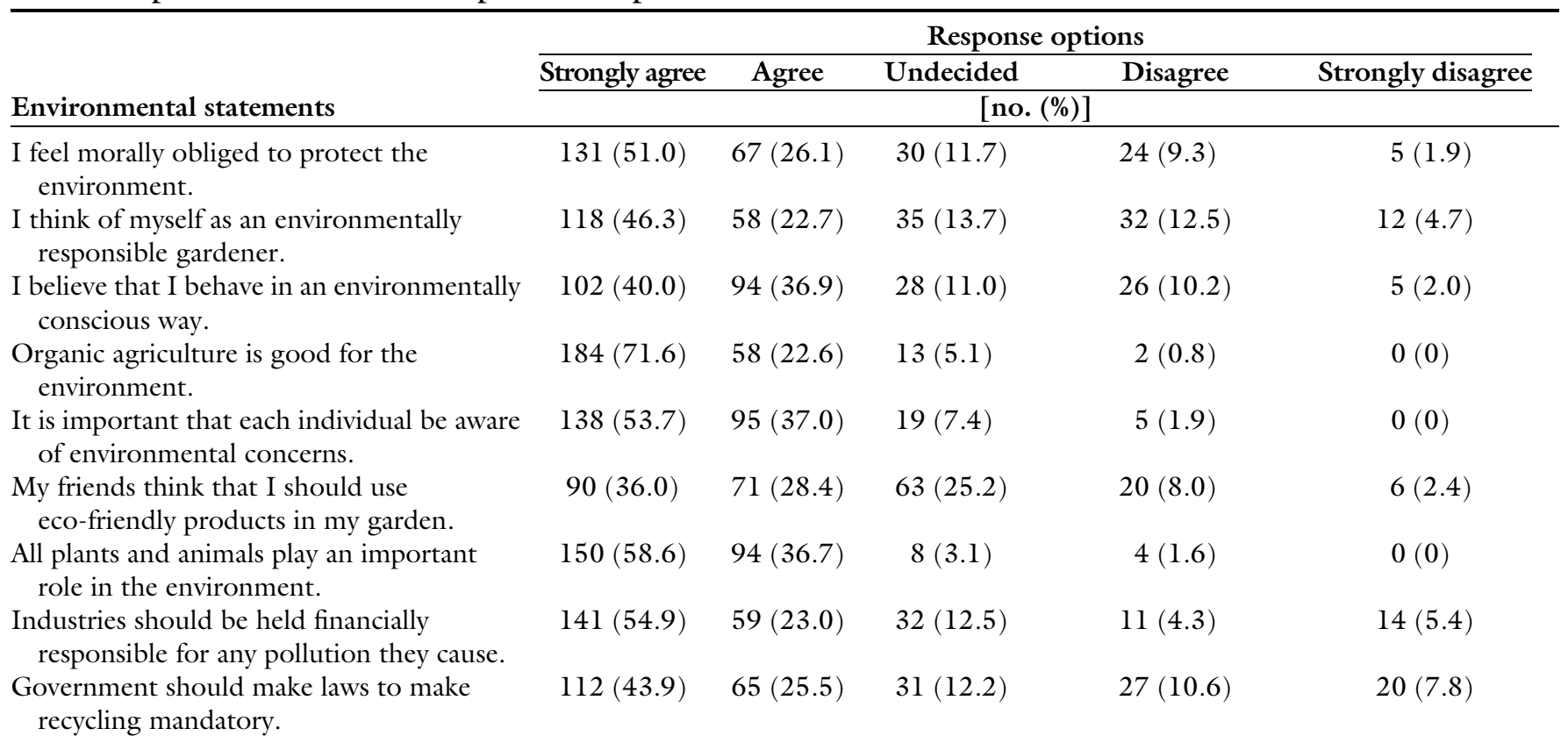

\begin{tabular}{|c|c|c|c|c|c|}
\hline Ethnocentricity statements & $\underline{\text { Strongly agree }}$ & Agree & Undecided & Disagree & Strongly disagree \\
\hline $\begin{array}{l}\text { It is not right to purchase foreign products, } \\
\text { because it puts Americans out of jobs. }\end{array}$ & $46(18.0)$ & $72(28.2)$ & $62(24.3)$ & $52(20.4)$ & $23(9.0)$ \\
\hline $\begin{array}{l}\text { Only those products that are not available } \\
\text { in the U.S. should be imported. }\end{array}$ & $42(16.4)$ & $84(32.8)$ & $80(31.3)$ & $32(12.5)$ & $18(7.0)$ \\
\hline $\begin{array}{l}\text { It is always best to purchase } \\
\text { American products. }\end{array}$ & $56(22.0)$ & $90(35.4)$ & $60(23.6)$ & $31(12.2)$ & $17(6.7)$ \\
\hline $\begin{array}{l}\text { American people should always buy } \\
\text { American products instead of imports. }\end{array}$ & $46(18.0)$ & $76(29.8)$ & $69(27.1)$ & $47(18.4)$ & $17(6.7)$ \\
\hline \multirow{2}{*}{$\begin{array}{l}\text { Locality: How often have you bought } \\
\text { food in the following categories? }\end{array}$} & Very often & Often & Occasionally & Rarely & Not at all \\
\hline & \multicolumn{5}{|c|}{$[$ no. (\%)] } \\
\hline Local eggs & $63(25.5)$ & $50(19.5)$ & $75(30.4)$ & $37(15.0)$ & $22(8.9)$ \\
\hline
\end{tabular}

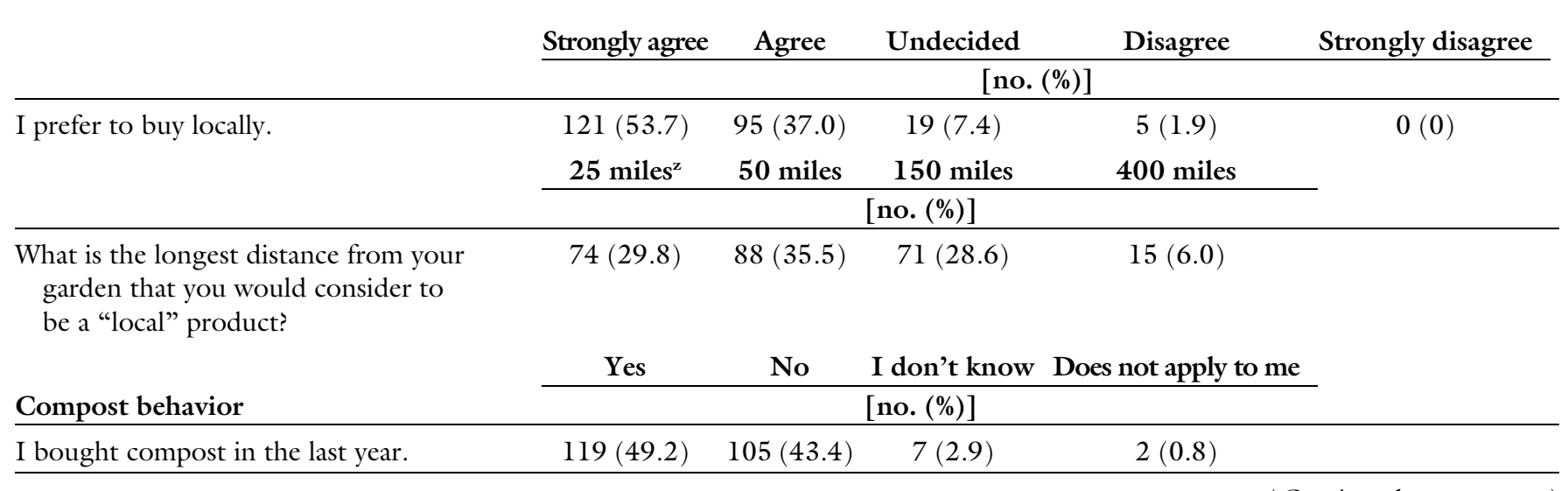

(Continued on next page) 
Table 1. (Continued) Descriptive statistics indicating the frequency and percentages of responses to individual statements in the study of the market potential of seaweed-incorporated compost.

\begin{tabular}{|c|c|c|c|c|c|}
\hline \multirow[b]{3}{*}{ Environmental statements } & \multicolumn{5}{|c|}{ Response options } \\
\hline & Strongly agree & Agree & Undecided & Disagree & Strongly disagree \\
\hline & \multicolumn{5}{|c|}{$[$ no. $(\%)]$} \\
\hline $\begin{array}{l}\text { My family and I used kitchen scraps, } \\
\text { leaf litter, and other organic materials } \\
\text { to make compost. }\end{array}$ & $90(39.0)$ & $131(56.7)$ & $3(1.3)$ & $7(3.0)$ & \\
\hline $\begin{array}{l}\text { I used chemical-based fertilizers on my } \\
\text { garden this year. }\end{array}$ & $163(75.1)$ & $43(19.8)$ & $11(5.1)$ & $0(0)$ & \\
\hline $\begin{array}{l}\text { I intend to use eco-friendly compost in } \\
\text { the garden in the next year. }\end{array}$ & $60(26.4)$ & $146(64.3)$ & $19(8.3)$ & $2(0.9)$ & \\
\hline \multirow{2}{*}{$\begin{array}{l}\text { When I've used compost in the past, my } \\
\text { plants seem healthier. }\end{array}$} & $41(19.0)$ & $139(64.4)$ & $31(14.4)$ & $5(2.4)$ & \\
\hline & $\$ 3$ or less & $\$ 4$ & $\$ 5$ & $\$ 6$ & $\$ 7$ or more \\
\hline Willingness to pay & \multicolumn{5}{|c|}{ [no. $(\%)]$} \\
\hline $\begin{array}{l}\text { What would be a base price you'd be } \\
\text { willing to pay for a } 1 \mathrm{ft}^{3} \text { bag, based } \\
\text { on the sample you see before you? }\end{array}$ & $18(7.7)$ & $88(37.4)$ & $63(26.8)$ & $50(21.3)$ & $16(6.8)$ \\
\hline $\begin{array}{l}\text { How much more would you be willing } \\
\text { to pay for each of the following } \\
\text { characteristics? }\end{array}$ & $+\$ 1$ & $+\$ 2$ & $+\$ 3$ & $+\$ 4$ & $+\$ 5$ or more \\
\hline
\end{tabular}

${ }^{\mathrm{z}} 1 \mathrm{mile}=1.6093 \mathrm{~km}$.

within the instrument, respondents were scored and classified into categories established a priori as positive, indifferent, or low. Similar groupings were established and used in interpreting results in previous studies (McFarland et al., 2008, 2010).

Potential compost Users' ENVIRONMENTAL ATTITUDE SCORES. Respondents were asked nine questions related to their environmental attitude. These questions were rated on a 5-point Likert scale. Examples of questions included, "it is important that each individual be aware of environmental concerns," "industry should be held financially responsible for any pollution they cause," "government should make laws to make recycling mandatory," and "all plants and animals play an important role in the environment" (Table 1). Possible answers to the statements included "strongly agree," "agree," "undecided," "disagree," and "strongly disagree." Responses of "strongly agree" received 5 points, while responses of "agree" received 4 points, responses of "undecided" received 3 points, responses of "disagree" received 2 points, and responses of "strongly disagree" received 1 point. Possible scores ranged from 5 to 45 points, and respondents were classified as having negative (5-15 points), indifferent (16-30 points), and positive (31-45 points) environmental attitudes based on their environmental attitude scores. The Cronbach's alpha reliability score for these questions was 0.905 .

Potential COMPOST USERS' VIEWS ON ETHNOCENTRICITY. Five ethnocentricity questions focused on whether American-made products are more desirable to participants and were rated on 5-point Likert scale. Examples of questions included "it is not right to purchase foreign products, because it puts Americans out of jobs" and "only those products that are not available in the U.S. should be imported." Possible answers were "strongly agree," "agree," "undecided," "disagree," and "strongly disagree", and points were attributed to responses as indicated above (Table 1). Possible scores ranged from 5 to 25 points and respondents were classified as having low (5-8 points), indifferent (916 points), and positive (17-25 points) ethnocentricity based on their ethnocentricity scores. These questions generated Cronbach's alpha of 0.925 .

Potential compost users' LOCALITY SCORES. The locality questions of the survey focused on respondents' 
local food-use. Respondents were presented with five statements relating to their locality, which were rated on 5-point Likert scale. Examples of questions included asking the respondent how often he/she had purchased various types of local food from categories, including local fresh fruits and vegetables, eggs, and dairy products (Table 1). Possible answers were "very often," "often," "occasionally," "rarely," and "not at all." Responses of "very often" received 5 points, while responses of "often" received 4 points, responses of "occasionally" received 3 points, responses of "rarely" received 2 points, and responses of "not at all” received 1 point. Possible scores ranged from 5 to 25 points, and respondents were classified as having negative (5-8 points), indifferent (916 points), and positive (17-25 points) attitudes toward locality based on their locality scores. Additional questions asked the farthest distance respondents considered to be local to them, as well as their overall preference for purchasing locally. A reliability analysis indicated a Cronbach's alpha of 0.741 for these questions (Table 1).

Potential compost users' COMPOST BEHAVIOR SCORES. The cOmpost behavior questions of the survey focused on respondents' compost-use in the garden. Respondents were presented nine statements relating to their compost behavior, and these statements were rated on a 4 -point scale that included the binary options of "yes" and "no," as well as the options of "I don't know" and "does not apply to me." Examples of questions included, "I intend to use eco-friendly compost in my garden in the next year” and, “when I've used compost in the past, I noticed that my plants seemed healthier." Responses of "yes" received 4 points, while responses of "no" received 3 points, responses of "I don't know" received 2 points, and responses of "does not apply to me" received 1 point (Table 1 ). Respondents were classified as being inexperienced (0-12 points), moderately experienced (13-24 points), or highly experienced (25-36 points) with compost based on their compost behavior scores. Possible scores ranged from 9 to 36 points. These questions generated Cronbach's alpha of 0.796 .

Potential compost USers' SELF-REPORTED WILLINGNESS TO PAY. The WTP questions of the survey were used to determine respondents' willingness to pay for this specialty blend compost. Questions and methods were shown to be valid and reliable in recent past studies (Glover et al., 2014; Short et al., 2017). Respondents were presented six statements rated on two different 6-point pricing scales for price of a $1-\mathrm{ft}^{3}$ bag: 1) $\$ 0, \$ 3$ or less, $\$ 4, \$ 5$, $\$ 6$, and $\$ 7$ or more, and 2) none, $\$ 1$, $\$ 2, \$ 3, \$ 4$, and $\$ 5$ or more. Examples of questions included, "what would be a base price you'd be willing to pay for a $1-\mathrm{ft}^{3} \mathrm{bag}$, based on the sample you see before you?" and, "assuming bags of compost are priced at $\$ 3.00 / \mathrm{ft}^{3}$ at your local nursery/garden center, how much more would you be willing to pay for each of the following characteristics?" (Table 1). Answers indicating greater values received 5 points and possible scores ranged from 0 to 30 points. Respondents were classified as having low (0-10 points), indifferent (11-20 points), or positive (21-30 points) WTP based on their WTP scores (Table 1). A reliability analysis indicated a Cronbach's alpha of 0.931 .

DATA ANALYSIS FOR POTENTIAL COMPOST USERS' SURVEY RESPONSES. Descriptive statistics and frequencies were used to analyze the data from the potential compost users. Individuals' WTP, environmental attitudes, locality, ethnocentricity, and compost behavior scores were compared with their age, education, household income, and gender. Using a SPSS statistical package (version 20; IBM, Armonk, NY), Pearson's product-moment tests were applied to assess the relationships between the above variables, and analysis of variance (ANOVA) tests were adopted to look for differences between the variables of interest. A lack of response to individual questions within the survey were treated as missing data within those cells.

\section{Results}

Potential compost users' SURVEY. Surveys were collected from 257 potential compost users. Demographics of this study are reflective of previous studies of similarly minded consumers of interest in farmers' market studies (Glover et al., 2014) and gardening studies (Boyer et al., 2002). In analyzing the demographics of the sample, the age of respondents was more heavily weighted toward younger groups with $40.6 \%$ of people surveyed being between 25-44 years, and 32.9\% being under 25 years old. The percentage of respondents who were between 45 and 59 years old was $21.3 \%$; only
$5.2 \%$ of respondents were over 60 years old (Table 2). Of all the participants in the sample, $55.1 \%$ were female and $44.9 \%$ were male (Table 2 ).

The sample was well educated and within the moderate to moderately high-income bracket. About, 47\% of the sample stated that they had achieved either bachelor's degree (29.2\%) or graduate degree $(20.6 \%)$, and $40.3 \%$ mentioned having either associate degree or some college with no degree (14.8\% and $25.5 \%$, respectively). Only 9.4\% of the sample indicated they had a high school diploma or a lower level education (Table 2). About 34\% of the sample was in the moderate to moderately high-income bracket of $\$ 35,000$ and \$74,999 (Table 2).

Potential compost USers' ENVIRONMENTAL ATTITUDE SCORES. The majority (78\%) of respondents had a positive environmental attitude, whereas $23 \%$ of respondents had an indifferent environmental attitude. No respondents had a low environmental attitude. For example, a little over $75 \%$ of respondents felt a moral obligation to protect the environment and behave in an environmentally conscious way (Table 1). Nearly 95\% of respondents agreed or strongly agreed that organic agriculture practices are good for the environment, while over $68 \%$ felt they were environmentally responsible gardeners (Table 1). Consistent with findings that the garden retail industry is influenced by sociocultural drivers that include consumer positive environmental attitudes and behavior (Horticultural Trades Association, 2017), these findings suggested that gardeners and those frequenting garden centers are inclined to have a positive environmental attitude.

Potential compost USers' VIEWS ON ETHNOCENTRICITY. Results showed that $47 \%$ of respondents ranked as having a positive ethnocentric attitude, whereas $46 \%$ of respondents ranked as having an indifferent ethnocentric attitude, and 7\% of respondents ranked as having a low ethnocentric attitude. For example, on all category statements, $25 \%$ to $30 \%$ of respondents were undecided regarding statements relating to products being American made (Table 1). While some studies show ethnocentric attitudes may impact purchasing decisions (Shimp and Sharma, 1987), others have found these beliefs may or may not hold true 
Table 2. Analysis of variance comparisons of willingness to pay (WTP) and the demographic variables of age, education, income, and gender in the study of the market potential of seaweed-incorporated compost.

\begin{tabular}{|c|c|c|c|c|c|c|}
\hline Group & [no. (\%)] & $\begin{array}{l}\text { WTP mean score } \\
(0-30 \text { scale })^{\mathrm{z}}\end{array}$ & SD & df & $F$ & $P$ \\
\hline Age group (years) & & & & 4 & 0.26 & 0.903 \\
\hline Under 25 & $82(32.9)$ & 16.207 & 7.929 & & & \\
\hline $25-44$ & $101(40.6)$ & 15.514 & 7.285 & & & \\
\hline $45-59$ & $53(21.3)$ & 15.886 & 7.397 & & & \\
\hline $60-84$ & $12(4.8)$ & 16.416 & 8.649 & & & \\
\hline $85+$ & $\mathrm{l}(0.4)$ & 10.000 & NA & & & \\
\hline Gender & & & & 1 & 1.46 & 0.228 \\
\hline Female & $134(55.1)$ & 16.350 & 7.656 & & & \\
\hline Male & $109(44.9)$ & 15.174 & 7.416 & & & \\
\hline Income & & & & 6 & 1.85 & 0.090 \\
\hline Less than $\$ 14,999$ & $55(23.1)$ & 16.345 & 7.359 & & & \\
\hline$\$ 15,000-\$ 24,999$ & $14(5.9)$ & 13.428 & 6.676 & & & \\
\hline$\$ 25,000-\$ 34,999$ & $42(17.6)$ & 13.381 & 6.431 & & & \\
\hline$\$ 35,000-\$ 74,999$ & $87(36.6)$ & 16.459 & 7.839 & & & \\
\hline$\$ 75,000-\$ 99,999$ & $22(8.6)$ & 17.318 & 6.917 & & & \\
\hline$\$ 100,000-\$ 149,999$ & $11(4.6)$ & 19.818 & 9.505 & & & \\
\hline$\$ 150,000$ and over & $7(2.9)$ & 14.857 & 7.335 & & & \\
\hline Education & & & & 6 & 2.69 & $0.015 *$ \\
\hline Less than ninth grade & $3(1.2)$ & 11.333 & 8.326 & & & \\
\hline Ninth-12th grade, no diploma & $3(1.2)$ & 23.333 & 1.527 & & & \\
\hline High school graduate or equivalent & $18(7.0)$ & 13.166 & 7.398 & & & \\
\hline Some college, no degree & $62(25.5)$ & 15.967 & 8.681 & & & \\
\hline Associate's degree & $36(14.8)$ & 12.750 & 4.789 & & & \\
\hline Bachelor's degree & $71(29.2)$ & 17.352 & 6.989 & & & \\
\hline Graduate or professional school/degree & $50(20.6)$ & 16.460 & 7.877 & & & \\
\hline
\end{tabular}

${ }^{\mathrm{z}}$ Higher WTP values indicated a greater price in WTP for the seaweed-incorporated compost whereas lower WTP indicated a lesser price in WTP for the seaweed-incorporated compost.

${ }^{*}$ Statistically significant at the 0.05 level.

in actual purchasing decisions (McLain and Sternquist, 1992).

Potential compost users' LOCALITY SCORES. Fifty percent of respondents ranked as having a positive locality attitude, whereas $43 \%$ of respondents ranked as having an indifferent locality attitude, and $7 \%$ of respondents ranked as having a negative locality attitude. Past research found farmers' market patrons to have a medium level of concern toward locally sourced foods (Glover et al., 2014). In this study, close to $90 \%$ of respondents said they prefer to buy locally, and most respondents felt that a product would be locally sourced if it was produced within 150 miles (Table 1 ).

Potential compost users' COMPOST BEHAVIOR SCORES. Almost 92\% of respondents ranked in the inexperienced in compost behavior category, whereas $8 \%$ of respondents ranked in the moderately experienced in compost behavior category, and less than $1 \%$ of respondents ranked in the highly experienced in compost behavior category. Therefore, in this study, most respondents considered themselves a novice regarding their purchase and use of compost. Most respondents in this study were using chemical-based fertilizers, weed-killers, and fungicides in their gardens (Table 1). Many reported purchasing compost at both big-box stores and local garden centers (Table 1). Most respondents also reported composting their own home organic waste (Table 1). Less than $20 \%$ reported having healthier plants after using compost in the past, and a little over $26 \%$ responded that they intended to purchase compost next year (Table 1). Walker et al. (2006) found in their survey study that $31 \%$ of respondents reported valuing compost as an alternative for chemical additives, with $64 \%$ reporting positive experiences with compost.

Potential compost users' SELF-REPORTED WILLINGNESS TO PAY. About, $15 \%$ of respondents ranked as having a positive WTP attitude, while $53 \%$ of respondents scored as having an indifferent WTP attitude, and 32\% of respondents had a low willingness to pay attitude. Respondents were most willing to pay $\$ 4.00 / \mathrm{ft}^{3}$ to $\$ 5.00 / \mathrm{ft}^{3}$ for seaweed-incorporated compost (Table 1 ). Most respondents reported they would pay $\$ 1.00$ to $\$ 5.00$ or more given additional information regarding the impact of the product on protecting from drought stress, the product being locally or Texas-produced, the product helping to divert organic materials from landfills, and the product being a naturally based (Table 1).

These results indicate a wide breadth of compost users' WTP among the study sample size. Compost prices range from $\$ 1.36$ (Lowes Companies, Mooresville, NC) to \$13.42 (Wal-Mart Stores, Bentonville, AR) per 40 - to $50-\mathrm{lb}$ or $\mathrm{l}$ - to $2-\mathrm{ft}^{3}$ bag. It should be noted as a limitation of the study that this research only looked at stated prices consumers claimed they would pay for the compost. Findings on the actual amount consumers would pay could vary had they been forced to purchase the compost.

DEMOGRAPHIC COMPARISONS OF WILLINGNESS TO PAY AMONG POTENTIAL COMPOST USERS. According to ANOVA results that compared the mean scores of each demographic 
category and their WTP, statistical significance $(P=0.015)$ was only found for education and WTP. Posthoc analysis (LSD) indicated "less than 9th grade," "9th to 12th grade, no diploma," "Associate degree," "high school graduate or equivalent," "Bachelor's degree," "some college, no degree," "graduate or professional degree," were significantly different from each other. However, based on the results of post-hoc analysis, there was not an obvious correlation between WTP and education levels of the participants. For all the other demographic variables, all groups within comparisons of age, gender, and income were similar in the potential price they were willing to pay for the specialty compost (Table 1). These findings were consistent with other horticultural product purchasing studies. For example, Short et al. (2017) found no difference in WTP regarding locally grown specialty cut sunflowers based on age, income, and education.

LOCALITY SCORE COMPARISONS. A Pearson's product-moment correlation indicated a positive correlation $(r=0.326, P<0.001)$ between WTP and locality scores. Therefore, as the locality scores increased, the potential users' willingness to pay increased as well (Table 3 ). Past research found consumers were willing to pay more for products indicating they were locally produced on the label (Hu et al., 2012).

COMPOST BEHAVIOR COMPARISONS. A Pearson's product-moment correlation indicated a positive correlation $(r=0.156, P=0.013)$ between WTP and compost behavior scores. Therefore, as the compost behavior scores increased, such that users with more compost use experience had higher behavior scores, the potential users' WTP increased as well (Table 3 ). This supports previous work showing that increased awareness of organic soil and compost products promotes market development (Eggerth et al., 2007; Tyler, 2001). Education and advertising regarding compost and its benefits is something the industry should pursue. Other agricultural advertising campaigns, such as "Go Texan" were successful in enlightening consumers in the past (Willcox, 2015).

Environmental attitude COMPARISONS. The results of the Pearson's product-moment correlation also indicated a positive correlation $(r=0.340, P<0.001)$ between WTP and environmental attitude scores. As environmental attitude scores increased, the potential users' WTP increased as well (Table 3 ). This finding supported past research indicating that environmental attitudes can influence consumer behaviors with those concerned with the environment buying more "green" products (Mainieri et al., 1997). Glover et al. (2014) also found a positive correlation between environmental attitudes and WTP (specifically for a native plant product as a local food source), and that respondents' attitudes to the environment were related to WTP.

ETHNOCENTRICITY COMPARISONS. A Pearson's product-moment correlation indicated a positive correlation

Table 3. Correlation matrix indicating the Pearson's product-moment correlation between willingness to pay (WTP) rating and environmental attitudes, locality, ethnocentricity, and compost behavior in the study of the market potential of seaweed-incorporated compost.

\begin{tabular}{lcc}
\hline Group & Pearson's correlation & $P$ \\
\hline Locality scores $^{\mathrm{z}}$ & 0.326 & $0.000^{*}$ \\
Compost behavior scores $^{\mathrm{y}}$ & 0.156 & $0.013^{*}$ \\
Environmental attitude scores $^{\mathrm{x}}$ & 0.340 & $0.000^{*}$ \\
Ethnocentricity scores $^{\mathrm{w}}$ & 0.169 & $0.006^{*}$ \\
\hline
\end{tabular}

${ }^{\mathrm{z}}$ Locality scores ranged from 5 to 25 points. Higher locality scores indicated a greater amount of locally produced products purchased by the participant, and a lower locality score indicated less locally produced products purchased by the participant.

${ }^{y}$ Compost behavior scores ranged from 0 to 36 points. Higher scores indicated more consumer experience in purchasing compost and compost products.

${ }^{x}$ Environmental attitude scores ranged from 5 to 45 points. Greater environmental attitude scores indicated a greater sensitivity to issues concerning the environment, and a lower environmental attitude scores indicated a lower sensitivity to issues concerning the environment.

${ }^{\text {w }}$ Ethnocentricity scores ranged from 5 to 25 points. Higher scores indicated a greater desire to purchase and promote American-made products.

${ }^{*}$ Statistically significant at the 0.05 level.

$(r=0.169, P=0.006)$ between WTP and ethnocentricity scores. So, as ethnocentricity scores increased, the potential users' WTP increased as well (Table 3).

Overall, results showed that participants who responded positively to buying local, buying compost in the past, having positive environmental attitudes, and buying American-made products were more likely to pay more for the seaweed-incorporated compost. Also, positive correlations were found regarding WTP and the following individual statements used to advertise the product (Assuming bags of compost are priced at $\$ 3.00 / \mathrm{ft}^{3}$ at your local nursery/garden center, how much more would you be willing to pay for each of the following characteristics?). For example, respondents were willing to pay more for "locally or Texas-produced compost" (Pearson's correlation $=0.952, P<0.001)$ or for a "natural-based product" (Pearson's correlation $=0.882, P<0.001)$. Those responding were also willing to spend more knowing they were "diverting materials from landfills" (Pearson's correlation $=0.951, P<0.001)$ or that the product would offer "protection against drought stress" (Pearson's correlation $=0.931, P<0.001)$. Thus, as indicated earlier with descriptive statistics, respondents said they would pay additionally if the seaweed-incorporated compost was advertised using these phrases (Table 3).

\section{Conclusions}

Because there have been a limited number of marketing studies that investigated the use of brown seaweed in compost and consumer WTP for seaweed-incorporated compost, this study provides a starting point for understanding the market opportunities for composting brown seaweed. Since the residential sector represents a sizeable market for soil amendments (Eggerth et al., 2007), results indicated there is potential for a specialty seaweed-incorporated compost to be introduced to the retail market, if the price is competitive. Overall, respondents were most willing to pay for seaweed-incorporated compost that was $\$ 4.00 / \mathrm{ft}^{3}$ to $\$ 5.00 / \mathrm{ft}^{3}$.

Interestingly, there was participant support for seaweed-incorporated compost despite a large majority of participants who ranked themselves as inexperienced in the compost behavior 
category. And, as compost behavior (i.e., more compost purchasing experience) scores increased, the potential users' WTP increased as well. Therefore, it is reasonable to assume that inexperienced users are likely not fully aware of the potential benefits of seaweed-incorporated compost. As noted by Eggerth et al. (2007), several marketing studies of organic soil amendments produced from various municipal waste sources have illustrated that market development is an issue of instilling awareness in potential users (Alexander, 2019). Eggerth et al. (2007) recommends that imparting awareness in the public is the first step where the compost market is small, which may be accomplished through education and salesmanship (Tyler, 2001). Because seaweed-incorporated compost is currently a small market within a growing compost market (Alexander, 2019), and study participants' lack of compost experience may be indicative of experience levels in general, a comprehensive education program is an area that needs further investigation in the future market development of this product. As reported by Alexander (2019), markets grow faster especially when compost education is provided as needed, and when several compost producers are competing within one geographic area.

When considering consumer attitudes, behavior, and future market development, it is clear participants who responded positively to the activities of buying local, buying compost in the past, having positive environmental attitudes, and buying American were more likely to pay more for the seaweed-incorporated compost. Because more informed gardeners recognize that not all composts have the same attributes, it is important to have an understanding of the competition to new products [such as a specialty compost product and in this case, a seaweed-incorporated compost (Alexander, 2019)]. Additionally, the lack of association of demographics to WTP is helpful when identifying potential compost consumers.

Overall, this project provided a path toward creating long-term sustainable use of resources and educating the public on the value of brown seaweed, both as habitat along the Gulf of Mexico shoreline and a horticultural asset. Results could be used to improve best management practices for ecologically and economically sustainable beach maintenance in coastal regions; however, future research is suggested. Specifically, composting studies should investigate the optimum inclusion rate of seaweed, as well as the approximate available amount of seaweed that could readily be composted in municipalities. Additionally, WTP studies could incorporate a comparison compost containing no specialty ingredients in future studies when surveying participants.

\section{Literature cited}

Alexander, R. 2019. Positioning your product for sales success. Biocycle 60:34-36.

Begum, M., B.C. Bordoloi, D.D. Singha, and N.J. Ojha. 2018. Role of seaweed extract on growth, yield and quality of some agricultural crops: A review. Agr. Rev. 39:321-326.

Boyer, R., T.M. Waliczek, and J.M. Zajicek. 2002. The Master Gardener program: Do benefits of the program go beyond improving the horticultural knowledge of the participants? HortTechnology 12:432-436.

Cole, A.J., D.A. Roberts, A.L. Garside, R. de Nys, and N.A. Paul. 2016. Seaweed compost for agricultural crop production. J. Appl. Phycol. 28:629-642.

Cornelissen, G., M. Pandelaere, L. Warlop, and S. Dewitte. 2008. Positive cueing: Promoting sustainable consumer behavior by cueing common environmental behaviors as environmental. Intl. J. Res. Mark. 25:46-55.

Dougherty, M. 1999. Field guide to onfarm composting. Natural Resources Coop. Ext. Agr. Eng. Serv. NRAES1 14.

Durande, N., X. Brian, and C. Meyer. 2003. The effect of marine bioactive substances (N PRO) and edogenouscytokinins on nitrate reductase activity in Arabidopsis thaliana. Physiol. Plant. 119:489-493.

Eggerth, L.L., L.F. Diaz, M.T.F. Chang, and L. Iseppi. 2007. Marketing of composts. Compos. Sci. Technol. 8:325-355.

Emerson, D. 2003. Building strong markets for mulch and compost products. Biocycle 44:36-40.

Eyras, M.C., C.M. Rosagno, and G.E. Defoss. 1998. Biological evaluation of seaweed compost. Compost Sci. Util. $6: 74-81$

Eyras, M.C., G.E. Defoss, and F. Dellatorre. 2008. Seaweed compost as an amendment for horticultural soils in Patagonia, Argentina. Compost Sci. Util. 16:119-124.

Faucette, B., J. Governo, and B. Graffagnini. 2003. Compost pricing and market survey in Georgia. Biocycle 44:32-33.

Foley, B.J. and L.R. Cooperband. 2002. Paper mill residuals and compost effects on soil carbon and physical properties. J. Environ. Qual. 31:2086-2095.

Gairdner, J. 2006. Local food is miles better: The farmers weekly food miles campaign. Reed Business Information, Crawley, UK.

Gaskill, M. 2015. Sargassum is ruining beaches from Texas to Tobago. 2 July 2019. <http://newsweek.com/2015/ $07 / 10 /$ sargassum-ruining-beachestexas-togago-347735.html>.

Getter, K. and B. Behe. 2013. Attitudes and awareness of a "buy local" holiday marketing campaign. HortTechnology 23:877-885.

Glover, B.J., T.M. Waliczek, and J.M. Gandonou. 2014. Self-reported willingness to pay for Texas persimmon fruit as a food source. HortTechnology 24:580589.

Horticultural Trades Association. 2017. HTA garden retail market analysis report. 5 Sept. 2019. <https://hta.org.uk/ learn-develop/market-information/ other-reports-and-resources.html>.

Hu, W., M.T. Batte, T. Woods, and S. Ernst. 2012. Consumer preferences for local production and other value-added label claims for a processed food product. Agr. Econ. 39:489-510.

Illera-Vives, M., S.L. Seoane, L.M. Brito, A. López-Fabal, and M.S. López-Mosquera. 2015. Evaluation of compost from seaweed fertilizer for horticultural use. Scientia Hort. 186:101-107.

Invasive Species Specialist Group. 2011. Global invasive species database. 2 July 2019. <http://www.issg.org/database/ welcome $/>$.

Iovieno, P., A. Leone, A. Alfani, L. Morra, and L. Pagano. 2009. Effect of organic and mineral fertilizers on soil respiration and enzyme activities of two Mediterranean horticultural soils. Biol. Fertil. Soils 45:555-561.

Khan, W., U. Rayirath, S. Subraanian, M. Jithesh, P. Rayorath, D.M. Hodges, A.T. Critchley, J.S. Craigie, J. Norrie, and B. Prithiviraj. 2009. Seaweed extracts as biostimulants of plant growth and development. J. Plant Growth Regul. 28:386-399.

Langin, K. 2018. Mysterious masses of seaweed assault Caribbean islands. 5 Sept. 
2019. <https://www.sciencemag.org/ news $/ 2018 / 06 /$ mysterious-massesseaweed-assault-caribbean-islands $>$.

Laudicina, V.A., L. Badalucco, and E. Palazzolo. 2011. Effects of compost input and tillage intensity on soil microbial biomass and activity under Mediterranean conditions. Biol. Fertil. Soils 47:63-67.

López-Mosquera, M.E., E. FernándezLemaa, R. Villaresa, R. Corralb, B. Alonso, and C. Blanco. 2011. Composting fish waste and seaweed to produce a fertilizer for use in organic agriculture. Procedia Environ. Sci. 9:113-117.

Mainieri, T., E. Barnett, T. Valdero, J. Unipan, and S. Oskamp. 1997. Green buying: The influence of environmental concern on consumer behavior. J. Soc. Psychol. 137:189-204.

McLain, S. and B. Sternquist. 1992. Ethnocentric consumers. J. Intl. Consum. Mark. 4:39-58.

McFarland, A., T.M. Waliczek, and J.M. Zajicek. 2008. The relationship between student use of campus green spaces and perceptions of quality of life. HortTechnology 18:232-238.

McFarland, A., T.M. Waliczek, and J.M. Zajicek. 2010. Graduate student use of campus green spaces and the impact on their perceptions of quality of life. HortTechnology 20:186-192.

McHugh, D.J. 2003. A guide to the seaweed industry. FAO Fisheries Tech. Paper 441. FAO, Rome, Italy.

Michalak, I., U. Miller, L. Tuhy, I. Sówka, and K. Chojnacka. 2017. Characterisation of biological properties of co-composted Baltic seaweeds in germination tests. Eng. Life Sci. 17:153-164.

PR Newswire. 2019. Global compost market report 2019: \$9.2 Billion market opportunities, trends, forecast and competitive analysis, 2013-2024. 4 Dec. 2019. <https:// www.prnewswire.com/news-releases / global-compost-market-report-2019-9-2billion-market-opportunities-trendsforecast-and-competitive-analysis-20132024-300931284.html>.

Rynk, R. 1992. On-farm composting handbook. NRAES-54. Northeast Regional Agr. Eng. Serv., Ithaca, NY.

Sahoo, D. 2000. Farming the ocean, p. 40. In: Seaweeds cultivation and utilization. Aravali Books Int., New Delhi, India.

Sembera, J.A., E.J. Meier, and T.M. Waliczek. 2018. Composting as an alternative management strategy for sargassum drifts on coastlines. HortTechnology 28:80-83.

Shani, D. and S. Chalasani. 1992. Exploiting niches using relationship marketing. J. Consum. Mark. 9:33-42.

Shimp, T.A. and S. Sharma. 1987. Consumer ethnocentrism: Construction and validation of the CETSCALE. J. Mark. Res. 24:280-289.

Short, K., C.L. Etheredge, and T.M. Waliczek. 2017. Studying the market potential for specialty cultivars of sunflower cut flowers. HortTechnology 27:611-617.

Sivasankari, S., V. Venkatesalu, M. Anantharaj, and M. Chandrasekaran. 2006. Effect of seaweed extracts on the growth and biochemical constituents of Vigna sinensis. Bioresour. Technol. 97:1745-1751.

Strik, W. and V.J. Staden. 1997. Isolation and identification of cytokinins in a new commercial seaweed product made from Fucus serratus L. J. App Pycol. 9:327330 .
Thirumaran, G., M. Arumugam, R. Arumugam, and P. Anantharaman. 2009. Effects of seaweed liquid fertilizer on growth and pigment concentration of Abelmoschus esculentes (1) medikus. Amer. Eurasian J. Agron. 2:57-66.

Turan, M. and C. Köse. 2004. Seaweed extracts improve copper uptake of grapevine. Acta Agr. Scand. 54:213-220.

Tyler, R. 2001. Beyond operations: The marketing imperative. Resour. Recycling 20(2):22-41.

van Kleef, E., H. van Trijp, and P. Luning. 2005. Consumer research in the early stages of new product development: A critical review of methods and techniques. Food Qual. Prefer. 16:192-201.

Verkleij, F.N. 1992. Seaweed extracts in agriculture and horticulture-A review. Biol. Agr. Hort. 8:309-324.

Walker, P., D. Williams, and T.M. Waliczek. 2006. An analysis of the horticultural industry as a potential value-added market for compost. Compost Sci. Util. 14:23-31.

Willcox, K. 2015. How do you define what makes a product local? It's complicated. 9 Sept. 2019. <https://vinepair. com/wine-blog/how-do-you-definelocal $/>$.

Yue, C., J. Dennis, B. Behe, C. Hall, B. Campbell, and R. Lopez. 2011. Investigating consumer preference for organic, local, or sustainable plants. HortScience 46:610-615

Zaffou, M. and B. Campbell. 2016. Consumer preference and willingness to pay for azaleas: Effect of state labeling and various types of retail outlets. HortScience 51:1026-1030.

Zhang, X., E.H. Ervin, and E.R. Schmidt. 2003. Plant growth regulators can enhance recovery of Kentucky bluegrass sod from head injury. Crop Sci. 43:952-956. 